\title{
KUALITAS PELAYANAN OMBUDSMAN PERWAKILAN KALIMANTAN SELATAN DALAM MENINDAKLANJUTI LAPORAN PENGADUAN MASYARAKAT KOTA BANJARMASIN
}

\author{
Service Quality of the South Kalimantan Representative Ombudsman in Following Up \\ the Banjarmasin City Complaint Report
}

\section{Beni Akhmad ${ }^{\prime *}$}

Mita Sari

Universitas Lambung Mangkurat, Banjarmasin, South Kalimantan, Indonesia

2Universitas Muhammadiyah Palangkaraya, Palangka Raya, Central Kalimantan, Indonesia

*email: beniap03@gmail.com

\section{Kata Kunci:}

Kualitas

Pelayanan

Ombudsman

Tindaklanjut Laporan

Keywords:

Quality

Service

Ombudsman

Report Follow-up

\section{Accepted}

March 2019

Published

June 2019

\begin{abstract}
Abstrak
Penelitian ini berfokus pada pemaparan kualitas pelayanan Ombudsman Republik Indonesia Perwakilan Kalimantan Selatan serta berbagai upaya yang dilakukan dalam menindaklanjuti laporan pengaduan masyarakat di kota Banjarmasin atas mala-administrasi yang dilakukan oleh birokrat di suatu instansi/ organisasi pemerintah penyelenggara layanan publik yang menghambat atau mengurangi pemenuhan pelayanan prima bagi publik. Pendekatan penelitian yang digunakan adalah kualitatif, penelitian ini menggunakan pedoman wawancara sebagai instrumen penelitian. Secara kualitatif penelitian ini menemukan bahwa, berdasarkan model kualitas layanan Gronroos, pelayanan Ombudsman Republik Indonesia Perwakilan Kalimantan Selatan dalam menindaklanjuti laporan pengaduan masyarakat sesuai dengan Undang-Undang Nomor 37 Tahun 2008 tentang Ombudsman Republik Indonesia dengan mengacu pada Pasal 24 sampai dengan pada Pasal 38, dalam menindaklanjuti laporan pengaduan masyarakat Ombudsman bersifat imparsial serta mampu menjadi fasilitator komunikasi yang efektif antara penyelenggara dengan pengguna pelayanan publik sehingga masingmasing pihak dapat memperoleh hak dan memenuhi kewajibannya. Penelitian menemukan faktor utama kendala pelayanan Ombudsman dalam menindaklanjuti laporan karena kurangnya informasi dan pengetahuan masyarakat tentang persyaratan formil dan materiil yang harus dilengkapi saat menyampaikan laporan pengaduan. Dari hasil penelitian tersebut, peneliti merekomendasikan meningkatkan informasi dan pengetahuan tentang fungsi, tugas dan wewenang Ombudsman dengan melakukan kegiatan sosialisasi kepada masyarakat, mahasiswa dan kepada penyelenggara pelayanan publik.
\end{abstract}

\begin{abstract}
This research focuses on exposure to the quality of service of the Ombudsman of the Republic of Indonesia Representative of South Kalimantan and various efforts made in following up reports on complaints from the public in Banjarmasin on administrative matters carried out by bureaucrats in public service agencies/organizations that hinder or reduce the fulfillment of excellent service for the people. The research approach used is qualitative. This study uses interview guidelines as a research instrument. Qualitatively, this study found that, based on the Gronroos service quality model, the service of the Ombudsman of the Republic of Indonesia Representative of South Kalimantan in following up public complaints reports in accordance with Law Number 37 of 2008 concerning the Ombudsman of the Republic of Indonesia with reference to Article 24 to Article 38, in following up on complaints from the public, the Ombudsman is impartial and able to be an effective communication facilitator between the organizer and users of public services so that each party can obtain rights and fulfill its obligations. The study found the main factor in the Ombudsman's service constraints in following up the report because of the lack of information and knowledge of the community about formal and material requirements that must be completed when submitting a complaint report. From the results of these studies, researchers recommend increasing information and knowledge about the functions, duties, and authorities of the Ombudsman by conducting socialization activities to the public, students, and public service providers..
\end{abstract}




\section{PENDAHULUAN}

Kualitas pelayanan adalah kesesuaian antara keinginan dan harapan dengan kenyataan, karena pelayanan publik adalah pemberian pelayanan kepada masyarakat yang merupakan perwujudan kewajiban aparatur pemerintahan sebagai abdi masyarakat dan memberikan pelayanan yang dapat memenuhi dan memuaskan kebutuhan pelanggan atau masyarakat secara baik atau terbaik (Wulan \& Mustam, 2017). Beberapa instansi pelayanan publik masih cenderung memperlihatkan kesan yang kurang baik, kesesuaian antara keinginan dan harapan dengan kenyataan yang didapatkan masyarakat sebagai pelanggan cenderung berbeda. Fenomena yang terjadi dalam proses pelayanan publik mendorong terbentuknya lembaga-lembaga pengawas dengan tujuan untuk mengawasi setiap proses pelayanan oleh penyelenggara pelayanan publik. Salah satu lembaga yang dibentuk untuk menjamin hak setiap warga Negara adalah ORI (Ombudsman Republik Indonesia). Ombudsman dalam memeriksa laporan tidak mengutamakan kewenangan yang bersifat memaksa namun Ombudsman dituntut untuk mengutamakan pendekatan persuasif kepada para pihak agar penyelenggara Negara dan pemerintahan mempunyai kesadaran sendiri dapat menyelesaikan laporan atas dugaan maladministrasi dalam penyelenggaraan pelayanan publik (Daim, 2019).

Keberadaan Ombudsman di daerah contohnya di Provinsi Kalimantan Selatan pada dasarnya mendapat respon positif dari masyarakat, meskipun pada realitanya keberadaan lembaga ini belum diketahui tugas dan fungsinya oleh mayoritas lapisan masyarakat (Marbun, 2016). Berikut laporan masyarakat terkait permasalahan-permasalahan pelayanan publik, adapun data laporan tahunan masyarakat kepada Ombudsman Perwakilan Kalimantan Selatan berdasarkan pada tahun 2014 sampai dengan tahun 2018 disajikan pada Tabel I sebagai berikut:
Tabel I. Jumlah Pengaduan Masyarakat ke Ombudsman Perwakilan Kalimantan Selatan dari Tahun 2014-2018

\begin{tabular}{ccc}
\hline No. & Tahun & Jumlah Pengaduan \\
\hline 1 & 2014 & 133 \\
2 & 2015 & 116 \\
3 & 2016 & 328 \\
4 & 2017 & 206 \\
5 & 2018 & 183 \\
\hline \multicolumn{3}{c}{ Total } \\
\hline
\end{tabular}

Sumber: Ombudsman Perwakilan Kalimantan Selatan Tahun 2018

Dari data diatas menunjukan akan kesadaran masyarakat untuk mendapatkan pelayanan publik yang lebih baik sudah semakin meningkat. Hal ini pula mengindikasikan bahwa pelayanan yang diberikan kesesuaian antara keinginan dan harapan dengan kenyataan belum diperoleh oleh sebagian masyarakat. Tingginya jumlah laporan ini pula mengindikasikan adanya peningkatan pemahaman tentang hak untuk mendapatkan pelayanan publik yang maksimal dari penyelenggara pelayanan publik (Sellang, 2016).

Diantara daerah lain di Kalimantan Selatan, Kota Banjarmasin merupakan daerah yang paling tinggi mendapatkan pengaduan. Dari fenomena ini untuk sementara bahwasannya dugaan maladministrasi banyak terjadi di wilayah kota Banjarmasin. Fenomena ini sudah sewajarnya mendapat perhatian khusus mengingat Ombudsman Perwakilan Kalimantan Selatan guna meningkatkan pelayanan publik ruang lingkup organisasi penyelenggara pelayanan publik mulai dari Pemerintahan Kota, SKPD (Satuan Kerja Perangkat Daerah), BUMD (Badan Usaha Milik Daerah), serta Badan Swasta atau Perorangan yang diberi tugas untuk menyelenggarakan pelayanan publik tertentu yang sebagian atau seluruhnya dananya bersumber dari APBD (Anggaran dan Pendapatan Belanja Milik Daerah) (Marbun, 2016). Sedangkan beberapa instansi yang dilaporkan masyarakat mengenai dugaan maladministrasi disajikan pada Tabel 2 sebagai berikut: 
Tabel 2. Jumlah Instansi yang Dilaporkan ke Ombudsman Perwakilan Kalimantan Selatan pada Tahun 2017

\begin{tabular}{clc}
\hline No & \multicolumn{1}{c}{ Instansi } & Jumlah Laporan \\
\hline I & Pertanahan & 35 \\
2 & Pendidikan & 23 \\
3 & Infrastruktur & 18 \\
4 & Kepolisian & 17 \\
5 & Kepegawaian & 16 \\
\hline & Total & 109 \\
\hline
\end{tabular}

Sumber: Banjarmasin Post, Kamis 28 Desember 2017

Dari data diatas cukup jelas instansi mana saja yang sering mendapatkan pengaduan dari masyarakat dengan demikian dugaan maladministrasi masih cenderung terjadi. Organisasi penyelenggara pelayanan publik yang seharusnya memberikan pelayanan yang baik, kepastian jangka waktu penyelesaian, mudah, terjangkau dan sikap petugas yang responsif sepertinya tidak didapatkan oleh masyarakat sebagai pelanggan. Dugaan maladministrasi ini mengharuskan Ombudsman Perwakilan Kalimantan Selatan untuk menjalankan tugas dengan baik supaya masyarakat terhindar dari dugaan pelanggaran penyelenggaraan pelayanan publik (Eka, 2017). Sebagai lembaga yang berfungsi untuk mengawasi pelayanan publik, Ombudsman mempunyai tugas untuk menerima laporan atas dugaan maladministrasi penyelenggaraan pelayanan publik, melakukan pemeriksaan substansial atas laporan, menindaklanjuti laporan yang tercakup dalam ruang lingkup kewenangan, melakukan investigasi, hingga menghasilkan rekomendasi dan saran atas dugaan maladministrasi penyelenggaraan pelayanan publik tersebut serta melakukan pencegahan maladministrasi dalam penyelenggaraan pelayanan publik (Alham, 2017). Berkaitan dengan hal tersebut, berdasarkan temuan awal saat wawancara dengan salah satu asisten Ombudsman Perwakilan Kalimantan Selatan terdapat permasalahan yang dihadapi Ombudsman Kalimantan Selatan itu sendiri, baik masalah internal dan eksternal. Internal: I) Kantor Perwakilan belum berbentuk satuan kerja, berimplikasi pada kelancaran anggaran yang menghambat program kerja; 2) Minimnya alokasi anggaran yang diberikan kepada Ombudsman perwakilan khususnya di bidang pencegahan dan penyelesaian laporan; 3) Belum adanya Jaminan Ketenagakerjaan (BPJS Ketenagakerjaan) bagi Insan Ombudsman. Eksternal: I) Rendahnya pemahaman dan komitmen Kepala Daerah dalam menindaklanjuti keluhan-keluhan pelayanan publik; 2) Belum optimalnya aparat pengawas intern atau kontrol pemerintah; 3) Belum optimalnya unit pengelolaan pengaduan yang ada di seluruh instansi pelayanan publik di Provinsi Kalimantan Selatan.

Sesuai pemaparan latar belakang permasalahan dan kendala yang dihadapi oleh Ombudsman Perwakilan Kalimantan Selatan maka perumusan masalah peneliti yaitu: (I). Bagaimana kualitas pelayanan Ombudsman Perwakilan Kalimantan Selatan dalam menindaklanjuti laporan pengaduan masyarakat kota Banjarmasin. (2). Apa saja kendala yang dihadapi Ombudsman Perwakilan Kalimantan Selatan dalam menindaklanjuti laporan pengaduan masyarakat kota Banjarmasin.

Berdasarkan latar belakang dan rumusan masalah penelitian ini maka tujuan penelitian peneliti dapat dirumuskan sebagai berikut: (I). Memaparkan dan menjelaskan tentang kualitas pelayanan Ombudsman Perwakilan Kalimantan Selatan dalam menindaklanjuti laporan pengaduan masyarakat kota Banjarmasin. (2). Memaparkan dan menjelaskan kendala yang dapat mempengaruhi kualitas pelayanan Ombudsman Perwakilan Kalimantan Selatan dalam menindaklanjuti laporan pengaduan masyarakat kota Banjarmasin.

\section{METODOLOGI}

Pendekatan penelitian ini menggunakan pendekatan kualitatif, dimana metode yang memfokuskan penelitian dengan memaparkan fenomena yang terjadi. Tipe penelitian yang digunakan adalah deskriptif. Menggunakan metode diskriptif dengan pendekatan induktif. Pengambilan sampel dilakukan dengan 
Probability Sampling dengan memberikan peluang yang sama bagi setiap unsur populasi untuk dipilih menjadi anggota sampel, dengan teknik simple random sampling. Penelitian yang dilakukan dengan pendekatan kualitatif menggunakan instrumen penelitian berupa pedoman wawancara karena dalam proses pengumpulan data menekankan pada wawancara mendalam terhadap narasumber atau informan.

\section{HASIL DAN PEMBAHASAN}

Secara teoritis kualitas layanan dilakukan adalah dengan mengukur harapan akan kualitas layanan (expected quality) dengan pengalaman kualitas layanan yang diterima (experienced quality). Dimensi kualitas yang dikemukakan Gronroos, baik buruknya image lembaga atau organisasi jasa tergantung dari bagaimana customer merasakan dimensi teknis (technical quality) dengan dimensi (functional quality) terkait proses. Pada akhirnya dapat menghasilkan image atau citra dari lembaga atau organisasi (Astuti, 2007). Model kualitas layanan yang pertama yaitu profesionalisme dan keterampilan adalah hasil yang terkait dan itu merupakan dimensi kualitas teknis. Kriteria terakhir, reputasi dan kredibilitas, sikap dan perilaku, aksesibilitas dan fleksibilitas, keandalan dan kepercayaan, dan pemulihan, semuanya terkait dengan proses dan karenanya mewakili dimensi kualitas fungsional (Prasastono \& Pradapa, 2012).

\section{Pengalaman Kualitas Layanan (Experienced Quality)}

Prinsip dasar dalam model ini adalah kualitas layanan bergantung perbandingan dua variabel, layanan yang diharapkan dari pelanggan dan layanan yang sebenarnya. Terdiri dari dua dimensi, yaitu dimensi teknis atau hasil dan dimensi fungsional atau terkait proses. Dalam hal ini hasil dari layanan (dimensi teknis), tetapi juga cara dalam yang layanan lakukan (dimensi fungsional) yang memberikan pengaruh pada persepsi pelanggan tentang layanan (Putro et al., 20I4). Adapun temuan peneliti beserta analisis hasil penelitian saat wawancara sebagai berikut:

\section{Teknis (profesionalisme dan keterampilan)}

Secara teknis prosedur pelayanan Ombudsman Perwakilan Kalimantan Selatan yang diberikan kepada masyarakat sesuai dengan Undang-Undang Nomor 37 Tahun 2008 dan Undang-Undang Nomor 25 Tahun 2009, prosedur pelayanan publik pada Ombudsman Perwakilan Kalimantan Selatan dilaksanakan secara keseluruhan, baik dalam tahapan pemeriksaan tertulis atau lapangan sampai pada tahapan penutupan laporan dan monitoring.

Penulis menganalisis bahwa aspek profesionalisme dan keterampilan secara teknis pelayanan publik pada Ombudsman Perwakilan Kalimantan Selatan yang telah dilaksanakan sesuai prosedur yang ditetapkan itu masih terlalu rumit untuk dipahami dan juga diterapkan di sebagian kalangan masyarakat. Prosedur yang dilaksanakan dan yang diterapkan oleh Ombudsman Perwakilan Kalimantan Selatan sesuai dengan UU No. 37 Tahun 2008 dengan mengacu pada Pasal 24 sampai dengan Pasal 38 diatur tentang mekanisme pengelolaan pengaduan atau penyelesaian laporan.

Hasil pemeriksaan Ombudsman Perwakilan Kalimantan Selatan berupa rekomendasi yang memuat uraian tentang laporan, uraian hasil pemeriksaan, bentuk maladministrasi yang terjadi dan kesimpulan atau pendapat Ombudsman Perwakilan Kalimantan Selatan mengenai hal-hal yang perlu dilaksanakan oleh terlapor. Remomendasi diartikan sebagai saran tetapi bisa juga disebut dengan nasehat yang disampikan oleh Ombudsman. Rekomendasi yang disampaikan Ombudsman kepada pejabat pemerintah atau penyelenggara Negara tentang apa yang harus dilakukan guna memperbaiki pelayanan yang dikeluhkan.

Berdasarkan pembahasan diatas bahwasannya pelayanan Ombudsman Perwakilan Kalimantan Selatan dalam hal mekanisme pelayanan yang didapatkan pelapor itu 
terlalu banyak persyaratan yang harus dilengkapi dan dipenuhi untuk penyelesaian laporan yang diadukan, hal demikian nantinya akan menjadi kendala tersendiri untuk masyarakat untuk menyampaikan laporan aduan yang disampaikan, minat atau keinginan masyarakat untuk melakukan aduan atau laporan mengenai permasalahan pelayanan publik menjadi berkurang karena terkendala banyaknya persyaratan yang harus dipenuhi, masyarakat beranggapan susah melengkapi persyaratan yang sudah di tetapkan oleh Ombudsman Perwakilan Kalimantan Selatan. Mempermudah persyaratan pengajuan laporan pengaduan secara tidak langsung akan menumbuhkan kepedulian masyarakat tentang permasalahan pelayanan publik yang terjadi, dengan persyaratan yang mudah maka masyarakat dengan sendirinya akan terobsesi untuk mengadu.

\section{Functional Quality (Proses)}

Berikut proses penanganan laporan masyarakat atas tindakan maladministrasi oleh penyelenggara Negara kepada lembaga Ombudsman Perwakilan Kalimantan Selatan. Pelapor datang melaporkan pengaduan kepada Ombudsman Perwakilan Kalimantan Selatan atas tindakan maladministrasi oleh penyelenggara Negara dengan syarat pelapor memuat nama lengkap, tempat dan tanggal lahir, status perkawinan, pekerjaan dan alamat lengkap. Pelapor juga memuat uraian peristiwa, tindakan atau keputusan yang dilaporkan secara rinci sudah menyampaikan laporan secara langsung kepada pihak terlapor atau atasannya, tetapi laporan tersebut tidak mendapatkan penyelesaian sebagaimana mestinya. Peristiwa, atau tindakan yang dilaporkan belum lewat 2 (dua) tahun sejak peristiwa tindakan atau keputusan yang bersangkutan terjadi dalam keadaan tertentu penyampaian laporan dapat dikuasakan kepada pihak lain dan dalam keadaan tertentu nama dan identitas pelapor dapat dirahasiakan (Pratiwie, 20I2).

\section{Reputasi dan Kredibilitas}

Ombudsman Perwakilan Kalimantan Selatan dalam melaksanakan penyelesaian laporan bersifat imparsial (tidak memihak) dan berada di tengah-tengah dalam artian Ombudsman Perwakilan Kalimantan Selatan menjadi fasilitator komunikasi yang terputus antara penyelenggara pelayanan dan pengguna layanan publik. Ombudsman berupaya selalu meningkatkan pelayanannya kepada masyarakat mengenai pengaduan yang disampaikan dengan menjalin hubungan melalui Memorandum of Understanding (MOU) dengan instansi terkait.

\section{Sikap dan Perilaku}

Ombudsman Perwakilan Kalimantan Selatan dalam menerima pengaduan dari masyarakat selalu bersikap ramah dan berperan aktif memberikan wawasan, menjelaskan secara singkat lembaga Ombudsman sebelum pelapor itu menceritakan apa permasalahannya, prosedur penyelesaian laporan yang dilakukan Ombudsman sesuai Undang-Undang Nomor 37 Tahun 2008, tidak bisa memberikan ketepatan waktu penyelesaian sebuah laporan tetapi laporan yang disampaikan selalu di proses sesuai prosedur yang berlaku di lembaga Ombudsman.

Aksesibilitas dan Fleksibilitas

Ombudsman Perwakilan Kalimantan Selatan memberikan akses yang mudah bila masyarakat ingin melakukan pengaduan pelayanan publik, bisa datang secara langsung ke kantor atau bahkan bisa melakukan pengaduan lewat telpon, email atau website dengan menceritakan permasalahannya diperkuat dengan bukti laporan yang disampaikan. Memberikan waktu seluas luasnya kepada masyarakat dalam menyampaikan laporan pengaduan dan pula selalu melayani aduan dari masyarakat sesuai dengan prosedur dan kewenangan lembaga Ombudsman.

\section{Kehandalan dan Kepercayaan}

Penyelesaian laporan yang disampaikan oleh pelapor atau masyarakat kepada Ombudsman Perwakilan Kalimantan Selatan tidak bisa sepenuhnya selesai 100\%, karna ada juga masyarakat yang menyampaikan di akhir 
tahun, belum lagi masalah koordinasi dengan instansi terkait itu memerlukan waktu, target terselesaikan dalam laporan tahunan yaitu sebesar $90 \%$ pengaduan yang disampaikan kepada Ombudsman Perwakilan Kalimantan Selatan.

Pemulihan

Dari sisi teknis adalah keterbatasan jumlah sumber daya aparatur, sehingga tidak rasio dengan jumlah beban penanganan laporan, sedangkan dari segi non teknis adalah karakteristik masyarakat kita yang sebagai pengeluh. Tujuan dari penyelesaian laporan pengaduan yang masuk pada Ombudsman Perwakilan Kalimantan Selatan sendiri, memang untuk tujuan memperbaiki pelayanan publik di Provinsi Kalimantan Selatan, terhadap kendala yang ada Ombudsman akan tetap memberikan pelayanan, karena kendala dalam memberikan pelayanan akan tetap selalu ada.

Ombudsman Perwakilan Kalimantan Selatan bertujuan membangun pundi-pundi kebaikan masa depan peradapan pelayanan Indonesia khususnya di kalimantan selatan sifatnya tidak memberi sanksi dia membangun pengaruh dia menyeimbangkan antara otoritas pelayanan publik dengan objektivitas perbaikan pelayanan publik, adapun yang dibagung Ombudsman Perwakilan Kalimantan Selatan itu kesadaran, bagaimana menumbuhkan kesadaran bahwa maladministrasi itu tidak baik, bahwa pelayanan publik itu hak orang, bahwa melayani itu pekerjaan mulia bukan berdasarkan sanksi tetapi memberi masukan pada kekuatan mempengaruhi, kekuatan kesadaran kalau dia sadar ada atau tiadanya Ombudsman dia akan bekerja dengan ritme peraturan yang sudah ditetapkan.

\section{Layanan Yang Diharapkan (Expected Quality)}

\section{Keberadaan Lembaga}

Keberadaan lembaga Ombudsman Perwakilan Kalimantan Selatan yang berada di Banjarmasin mendapat respon yang positif di kalangan masyarakat, ada harapan besar bagi masyarakat terhadap lembaga
Ombudsman untuk kedepannya yaitu pelayanan yang ada di Kalimantan Selatan khususnya di Banjarmasin menjadi lebih baik dan memenuhi hak-hak sebagai pengguna pelayanan publik.

\section{Komunikasi}

Sosialisasi yang dilakukan lembaga Ombudsman nyatanya masih belum efektif, ada saja masyarakat yang tidak mengetahui dengan fungsi lembaga Ombudsman secara langsung. Hal ini mempengaruhi pengetahuan masyarakat untuk melakukan pengaduan mengenai prosedur, syarat dan kewenangan Ombudsman itu sendiri, demikian pula menjadi hambatan dalam penerimaan dan verifikasi laporan dikarenakan syarat yang kurang lengkap. Apabila masyarakat itu tahu dan melengkapi persyaratan maka laporan yang masuk ke lembaga Ombudsman segera ditindaklanjuti.

\section{Citra Lembaga}

Lembaga Ombudsman memang terdengar terkenal di masyarakat perkotaan tetapi bila keluar dari perkotaan lembaga Ombudsman tersebut terdengar asing di kalangan masyarakat. Hanya terlintas sebagai lembaga penerima pengaduan dan hanya mendamaikan kedua belah pihak dengan proses penyelesaian yang panjang.

Dari Mulut ke Mulut

Masyarakat yang menyampaikan laporan pengaduan kelembaga Ombudsman Perwakilan Kalimantan Selatan hanya bila tersangkut masalah pribadi terhadap pelayanan yang diterima bukan sebagai masyarakat yang selalu peduli terhadap permasalahan pelayanan publik yang terjadi di lingkungan masyarakat.

\section{Kebutuhan Masyarakat}

Dengan berdirinya lembaga Ombudsman Perwakilan Kalimantan Selatan, harapannya dengan adanya lembaga tersebut diharapkan mampu menyelesaikan pengaduan yang di sampaikan masyarakat buka cuma sebagai lembaga pengaduan yang hanya sebagai rutinitas menerima laporan masyarakat. Harapan besar dari 
masyarakat bahwa pelayanan publik yang diterima menjadi lebih baik dan pemenuhan hak-hak sebagai pengguna pelayanan publik.

\section{Kendala - Kendala Ombudsman Perwakilan Kalimantan Selatan}

Berdasarkan data hasil penelitian yang diperoleh tampak bahwa kendala pelayanan publik pada Ombudsman Perwakilan Kalimantan Selatan sangat perlu untuk diatasi karena nantinya akan mempengaruhi kualitas pelayanan yang diberikan oleh Ombudsman dalam menyelesaikan laporan pengaduan masyarakat. Berikut beberapa kendala yang dihadapi Ombudsman Perwakilan Kalimantan Selatan, yaitu:

\section{Teknologi Informasi}

Kendala yang pertama kurangnya informasi masyarakat tentang persyaratan formil dan materil yang harus dilengkapi saat menyampaikan laporan pengaduan. Menurut Jogiyanto (2009), sistem teknologi informasi memberikan lima peran utama di dalam organisasi, yaitu untuk meningkatkan efisiensi, efektivitas, komunikasi, kalaborasi dan kompetitif.

Berdasarkan analisa dapat disimpulkan bahwa teknologi dan informasi belum dimanfaatkan secara optimal oleh kalangan masyarakat, mereka lebih cendrung mendengarkan atau terlibat secara langsung dalam sosialisasi yang diberikan lembaga Ombudsman Perwakilan Kalimantan Selatan, untuk mengatasi kendala tersebut hendaknya Ombudsman Perwakilan Kalimantan Selatan berpedoman pada dasar hukum Ombudsman Republik Indonesia yaitu yang terdapat pada keputusan Presiden Nomor 44 Tahun 2000 bahwa Ombudsman Republik Indonesia mempunyai tugas menyebarluaskan pemahaman mengenai lembaga Ombudsman, melakukan koordinasi dan kerjasama dengan instansi pemerintahan dan sebagainya. Bisa melakukan sosialisasi secara langsung saat melakukan investigasi lapangan di daerah yang memang jauh keberadaannya dari kantor Ombudsman perwakilan ada upaya dari Ombudsman memperkenalkan fungsi, tugas dan wewenang kepada masyarakat, jadi mendapatkan hasil ganda, pertama melakukan inverstigasi lapangan atas laporan pengaduan dan yang kedua sekaligus memperkenalkan Ombudsman kepada masyarakat.

\section{Keterbatasan Anggaran}

Kendala yang kedua terkait keterbatasan anggaran atau keuangan. Menurut Rahayu dan Rachman (2013), anggaran merupakan alat perencanaan dan pengendalian. Adapun perencanaan adalah pandangan ke depan untuk melihat tindakan apa yang seharusnya dilakukan agar dapat mewujudkan tujuan-tujan tertentu, sedangkan pengendalian adalah melihat ke belakang, memutuskan apa yang sebenarnya telah terjadi dan membandingkannya dengan hasil yang direncanakan sebelumnya.

Penulis menganalisis hal ini nantinya akan mempengaruhi kinerja Ombudsman Perwakilan Kalimantan Selatan dalam hal menginvestigasi atau menindaklanjuti laporan ke lapangan yang ada di daerah-daerah provinsi yang membutuhkan jarak tempuh yang jauh secara tidak langsung berdampak terhadap kualitas pelayanan yang diberikan, karena tidak optimalnya kinerja. Untuk meminimalisir anggaran yang terbatas, laporan pengaduan dari masyarakat dapat dikelompokan sesuai substansi laporan atau lokasi daerah, jadi sekali investigasi lapangan bisa menangani 5 sampai 6 laporan dalam sekali jalan hal ini dapat menekan anggaran yang terbatas.

\section{Respon Dari Terlapor}

Kendala ketiga yaitu terkait dengan respon dari penyelenggara Negara yang menjadi terlapor. Menurut Schumaker dan Getter (1977) responsif ialah tindak balas di antara permintaan dan penunaian terhadap permintaan tersebut. Kurangnya respon dan komitmen instansi terlapor menindaklanjuti keluhan-keluhan masyarakat sebagai pengguna pelayanan publik berdampak pada lamanya penyelesaian laporan 
pengaduan yang ditangani Ombudsman. Beberapa dari penyelenggara Negara atau instansi sering berlarut-larut dalam penyelesaian laporan, hal demikian yang menyebabkan pelayanan yang diberikan Ombudsman Perwakilan Kalimantan Selatan kepada masyarakat yang menjadi pelapor menjadi tidak efektif serta laporan tersebut akan lama selesai yang asalnya bisa diselesaikan dalam waktu 2 minggu ternyata menjadi I bulan lebih dalam penyelesaiannya. Solusi untuk menghadapi kendala tersebut adalah dengan ketika kunjungan ke instansi manapun diupayakan untuk meminta kotak person atau kotak petugas pengelola pengaduan. Jadi apabila ada laporan di instansi tersebut maka Ombudsman Perwakilan Kalimantan Selatan dapat langsung menghubungi ke pejabatnya agar dapat mendapatkan respon dari instansi yang bersangkutan.

Berbagai kendala yang ada di lembaga Ombudsman Perwakilan Kalimantan Selatan, menurut penulis Ombudsman Perwakilan Kalimantan Selatan perlu meminimalisir kendala tersebut agar nantinya tetap mampu meningkatkan kualitas pelayanan Ombudsman khususnya dalam hal pelayanan menindaklanjuti laporan pengaduan, menyebarluaskan pemahaman kepada masyarakat tentang fungsi, tugas dan wewenang Ombudsman Perwakilan Kalimantan Selatan, serta berpedoman pada dasar hukum Ombudsman Republik Indonesia yaitu yang terdapat pada keputusan Presiden Nomor 44 Tahun 2000 bahwa Ombudsman Republik Indonesia mempunyai tugas menyebarluaskan pemahaman mengenai lembaga Ombudsman, melakukan koordinasi dan kerjasama dengan instansi pemerintahan. Dengan informasi dan pengetahuan masyarakat tentang fungsi, tugas dan wewenang Ombudsman maka diharapkan masyarakat dapat berkontribusi dalam meningkatkan pelayanan public.

\section{KESIMPULAN}

Pelayanan Ombudsman Perwakilan Kalimantan Selatan dalam menindaklanjuti laporan pengaduan masyarakat sesuai dengan UU No. 37 Tahun 2008 tentang Ombudsman Republik Indonesia yaitu dengan mengacu pada Pasal 24 sampai dengan Pasal 38 diatur tentang mekanisme pengelolaan pengaduan atau penyelesaian laporan, dalam menindaklanjuti laporan pengaduan masyarakat Ombudsman bersifat imparsial serta mampu menjadi fasilitator komunikasi yang efektif antara penyelenggara dengan pengguna pelayanan publik sehingga masing-masing pihak dapat memperoleh hak dan memenuhi kewajibannya. Meskipun dalam penanganannya terdapat beberapa kendala-kendala yang dihadapi pertama, kurangnya pengetahuan masyarakat tentang persyaratan formil dan materil yang harus dilengkapi. Kedua, keterbatasan anggaran yang dimiliki khususnya anggaran bidang pencegahan dan pemeriksaan laporan pengaduan, dan. Ketiga, terkait respon dari instansi yang menjadi terlapor, kurangnya respon dan komitmen instansi terlapor menindaklanjuti keluhan-keluhan yang disampaikan masyarakat.

\section{REFERENSI}

Alham, A. 2017. Kewenangan Lembaga Ombudsman dalam Mengawasi Tindakan Penyalahgunaan Wewenang oleh Pemerintah Ditinjau dari Undang-Undang Nomor 37 Tahun 2008 tentang Ombudsman Republik Indonesia. Legal Opinion: Jurnal Ilmu Hukum, 5, I-I7.

Astuti, H.J. 2007. Analisis Kepuasan Konsumen (Servqual Model dan Important Performance Analysis Model). Media Ekonomi, 7, I-20.

Daim, N.A. 2019. Urgensi Pengaturan Lembaga Negara Khusus dalam Undang-Undang Dasar 1945. Jurnal Konstitusi, 16, 105-126.

Eka, E. 2017. Kualitas Pelayanan Publik di Kantor Camat Rumbai Pesisir. Jurnal Niara, 9, 100-109.

Jogiyanto, H.M. 2009. Sistem Informasi. Yogyakarta: Andi Offset.

Marbun, F.H. 2016. Kinerja Ombudsman Republik Indonesia Perwakilan Provinsi Riau dalam Penanganan Laporan Masyarakat Kota Pekanbaru. Jurnal Online Mahasiswa Fakultas IImu Sosial dan Ilmu Politik Universitas Riau, 3, I-II. 
Prasastono, N. \& Pradapa, S.Y.F. 2012. Kualitas Produk dan Kualitas Pelayanan Terhadap Kepuasan Konsumen Kentucky Fried Chicken Semarang Candi. Dinamika Kepariwisataan, I I, 13-23.

Pratiwie, D.W. 2012. Urgensi Keberadaan Ombudsman Republik Indonesia dalam Rangka Mewujudkan Good Governance (Ditinjau dari Undang-Undang Nomor 37 Tahun 2008 tentang Ombudsman Republik Indonesia). Yuriska: Jurnal Ilmiah Hukum, 4, 63-79.

Putro, S.W., Semuel, H., \& Brahmana, R.K. 2014. Pengaruh Kualitas Layanan dan Kualitas Produk Terhadap Kepuasan Pelanggan dan Loyalitas Konsumen Restoran Happy Garden Surabaya. Jurnal Manajemen Pemasaran, 2, I-9.

Rahayu, S. \& Rachman, A.A. 2013. Penyusunan Anggaran Perusahaan. Yogyakarta: Graha IImu.

Schumaker, P.D. \& Getter, R.W. 1977. Responsiveness Bias. American Journal of Political Science, 21, 567-600.

Sellang, K. 2016. Administrasi dan Pelayanan Publik: Antara Teori dan Aplikasinya. Yogyakarta: Penerbit Ombak.

Undang-Undang Nomor 37 Tahun 2008 tentang Ombudsman Republik Indonesia

Wulan, R.R. \& Msutam, M. 2017. Peningkatan Kualitas Pelayanan Publik dalam Rangka Reformasi Birokrasi di Kantor Pertanahan Kota Semarang. Journal of Public Policy and Management Review, 6, 259-279. 